
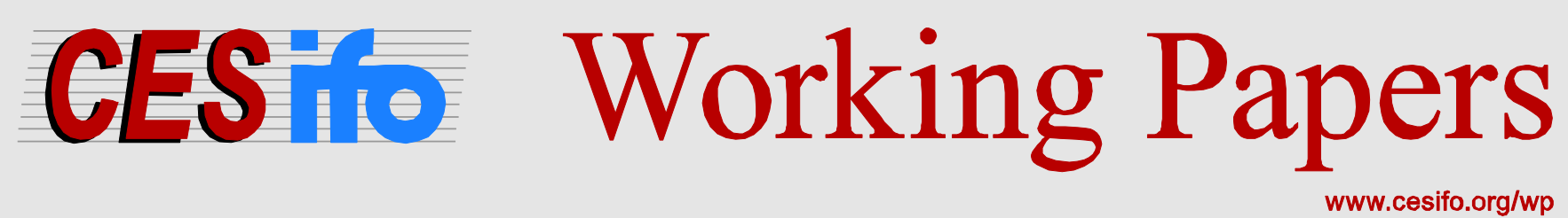

\title{
Financial Frictions and Foreign Direct Investment: Theory and Evidence from Japanese Microdata
}

\author{
Horst Raff \\ Michael Ryan \\ Frank Stähler
}

CESIFO WORKING PAPER NO. 5260

CATEgORY 8: TRADE POLICY

MARCH 2015

An electronic version of the paper may be downloaded
- from the SSRN website:
- from the RePEc website:
from the CESifo website: 


\title{
Financial Frictions and Foreign Direct Investment: Theory and Evidence from Japanese Microdata
}

\begin{abstract}
We use Japanese microdata to examine how financial market frictions affect foreign direct investment (FDI). The Japanese land price bubble and banking trouble in the late 1980s and early 1990s serve as a quasi natural experiment to identify two possible transmission channels from financial shocks to FDI: (i) a collateral channel, whereby changes in the value of collateral affect investors' ability to borrow; and (ii) a lending channel, whereby changes in bank health affect banks' ability to lend. We find evidence that both transmission channels are statistically significant and economically important.
\end{abstract}

JEL-Code: F230, L200.

Keywords: foreign direct investment, multinational enterprise, financing, credit rationing, collateral, bank health, Japan.

\author{
Horst Raff* \\ Department of Economics \\ Kiel University \\ Wilhelm-Seelig-Platz 1 \\ Germany - 24118 Kiel \\ raff@econ-theory.uni-kiel.de
}

\author{
Michael Ryan \\ Department of Economics \\ Western Michigan University \\ 1903 W. Michigan Ave. \\ USA - Kalamazoo, MI 49008 \\ michael.ryan@wmich.edu
}

\author{
Frank Stähler \\ Department of Economics \\ University of Tübingen \\ Mohlstr. 36 (V4) \\ Germany - 72074 Tübingen \\ frank.staehler@uni-tuebingen.de
}

*corresponding author

March 10, 2015 


\section{Introduction}

The global financial crisis was accompanied by a worldwide collapse of foreign direct investment (FDI). According to UNCTAD (2011, Table I.1), world outflows of FDI were $46 \%$ lower in 2009 compared to 2007, with the drop in outflows from developed countries exceeding 50\%. Such a collapse of FDI is worrying because FDI has been one of the main driving forces of globalization in the past decades: foreign affiliate sales have exceeded world trade for more than two decades (see UNCTAD, 2004). Moreover, FDI plays an essential role as a source of investment capital not least for less-developed countries, a source that has traditionally been thought to be much less volatile than portfolio capital (UNCTAD, 2011).

While the financial crisis obviously had drastic consequences for FDI, it remains unclear what exactly caused FDI to fall. UNCTAD (2011) argues that the main reason for the drop in FDI was the economic downturn and that FDI has been slow to recover due to the fragile world economy and an uncertain regulatory environment. This conclusion is in line with the traditional industrial organization view of FDI, where FDI is based on product or technology market imperfections, but financial markets are assumed to be frictionless (see, for instance, Markusen, 2002, or Barba Navaretti and Venables, 2004). According to this view, not only are changes in FDI flows mainly due to product market shocks, there are also no drastic consequences for social welfare when firms simply adjust their FDI to changing demand conditions.

The current paper argues that this traditional view is incomplete in that financial frictions may have potentially strong effects on FDI. More precisely, we demonstrate that FDI may react strongly to credit constraints and that a decline in FDI due to tighter credit constraints may be bad for welfare, as socially desirable investment projects may not get funded. But we go further in our analysis. Specifically we examine how financial shocks are transmitted to FDI. We focus on two possible transmission channels: (i) a lending channel, whereby changes in bank health affect banks' ability to lend; and (ii) a collateral channel, whereby changes in the value of collateral 
affect investors' ability to borrow.

We base our analysis on microdata on Japanese FDI projects in the United States between 1980 and 1994. These data are ideally suited for our purpose: First, the time period includes the Japanese land-price bubble, and land in Japan as elsewhere is the dominant form of collateral to secure loans. Following a steep rise in the second half of the 1980s, land prices in Japan dropped by more than half between 1990 and 1993. The changes in land prices are exogenous to the investing firms (see also Gan, 2007a,b). Second, Japanese companies, even large ones, rely heavily on bank financing, more so than, for instance, firms in the United States. Many of these companies saw the health of their main bank decline starting in the mid 1980s. Third, the financial crisis was by and large confined to Japan, local demand conditions in the United States were stable. Hence the gross return from FDI projects in the United States was arguably not affected by the financial trouble in Japan (Klein et al., 2002). These arguments make it persuasive that the strong increase in Japanese FDI projects in the United States from the mid-1980s until 1990 and the subsequent drop were at least in part driven by financial conditions in Japan, in particular by changes in land values and changes in bank health.

Our empirical analysis is based on a simple theoretical model specifying how credit constraints affect multinational investment. Unlike the well known models of FDI that focus exclusively on product market imperfections and incompleteness of contracts for intermediate goods, technology and headquarter services, we concentrate on the microfoundations of credit constraints while abstracting from questions regarding the location, trade and competitive effects of multinationals. ${ }^{1}$ Following the seminal contribution by Stiglitz and Weiss (1981), credit rationing occurs in our model due to incomplete information about the riskiness of an investment. Simply put, banks have to impose tough credit terms to deter projects with a low success probability. The probability that a project will be financed is hence less than one and turns out to be increasing in bank health.

\footnotetext{
${ }^{1}$ We agree with Markusen (2002) that it makes sense conceptually to separate decisions about production location and trade from financing decisions.
} 
A role for collateral arises from the incompleteness of loan contracts: banks require collateral to prevent borrowers from accepting tough credit terms only to then default on the loan. A change in collateral value hence, too, affects the investor's ability to borrow. While lower bank health and a lower collateral value both reduce the probability that an investment receives financing, we show that the two channels have very different implications for the likelihood that a socially desirable project receives funding and hence for the allocative efficiency of financial markets. Thus it is important to distinguish between them empirically.

By identifying the separate effects of the lending and the collateral channel and showing that economically sizeable and statistically significant effects emanate from both, our paper contributes to the growing literature on the effects of financial constraints on FDI and trade (see Foley and Manova (2014) for a recent survey). It builds on the seminal papers by Froot and Stein (1991) and Klein et al. (2002) who were the first to point out the importance of financial constraints for FDI. Froot and Stein show that a domestic currency depreciation raises the relative wealth of foreign investors, giving them an advantage over domestic investors in bidding for take-over targets. Klein et al. argue that the decline in Japanese FDI after 1990 cannot be explained by this relative-wealth (RW) hypothesis alone, but that the decline is more consistent with weak credit markets caused by the decreasing health of Japanese banks. ${ }^{2}$ They show that FDI by Japanese firms is significantly affected by the health of their main banks - what they term the relative-access-to-credit (RAC) hypothesis. ${ }^{3}$

The current paper complements these two hypotheses by showing that the collateral channel plays an important and independent role in transmitting financial shocks to FDI. That is, controlling for the RW and the RAC hypotheses as well as for key firm characteristics, we find that the value of

\footnotetext{
${ }^{2}$ See also Klein and Peek (1994) for further empirical evidence on the RW hypothesis.

${ }^{3}$ Alba et al. (2007) confirm the results of Klein et al. (2002) and show that bank downgrades affect the FDI even of those firms that have access to bond markets and thus could have financed their investment through bonds. Gibson (1995) shows that bank health affects investment: investment is $30 \%$ lower for firms that have one of the lowestrated banks as their main bank.
} 
a firm's land holdings has a significant effect on FDI activity. This collateral effect turns out to be particularly strong in the second half of the 1980s, which helps explain the strong increase in Japanese FDI at that time. ${ }^{4}$

The paper is also connected with the corporate finance literature on the collateral and lending channels. Gan (2007a) uses the bursting of the Japanese real estate bubble to identify the effect of a shock to firms' collateral on fixed investment, which in turn is computed using changes in the capital stock and depreciation. Gan finds a statistically and economically significant impact of the drop in collateral value: a 10 percent decrease in land values leads to a 0.8 percent reduction in the investment rate. Using data at the individual loan level, Gan (2007b) identifies a loan supply shock stemming from banks' real estate exposure. She observes that firms reduce their borrowing from banks with greater exposure to the real-estate market. Gan estimates that this lending channel accounts for $20 \%$ of the decline in fixed investment and $25 \%$ of the drop in stock market value of Japanese firms. Chaney et al. (2011) use data for the period 1992 to 2007 to study the effect of changes in real estate prices on corporate investment in the United States. They find support for the importance of the collateral channel, with an additional dollar of collateral boosting investment of the average firm by 6 cents.

An obvious difference between these corporate finance papers and ours is that we look at a very specific and important form of investment, namely FDI. But FDI is not only interesting in itself. Rather our focus on new FDI projects has the distinct advantage of allowing us to control for demand conditions in the host country and thus the gross return on investment, which is hard to do when looking at aggregate corporate investment, as domestic

\footnotetext{
${ }^{4}$ Another related paper is by Buch et al. (2009) who model the effect of credit constraints on FDI and, conditional on FDI, on the size of overseas operations. Using microdata on German FDI they find that a larger cash flow raises the propensity to invest abroad and to have more overseas affiliates. We, too, control for cash flow, but go further by, among other things, examining the role of bank health and collateral value. Manova, Wei and Zhang (2014) find that foreign-owned firms perform better in China under credit constraints because they have access to credit through their parent firms. Matsuyama (2005), among others, shows that countries with better-functioning financial markets have a comparative advantage for hosting industries that rely substantially on external credit.
} 
financial shocks typically go hand in hand with changes in domestic demand conditions.

Finally our findings mirror to some extent what other authors have found regarding the effect of financial constraints on international trade. Amiti and Weinstein (2011), for instance, use Japanese microdata to look for a lending channel in exports. They regress firm-level exports on a proxy of the health of the firm's main bank, and find that declining bank health significantly hurts exports. ${ }^{5}$

The remainder of the paper is organized as follows. In the next section we develop a theoretical model to provide a micro-foundation for the financial frictions affecting FDI. In Section 3 we present the Japanese data and discuss stylized facts. In Section 4 we introduce our regression model and results. Section 5 concludes. The Appendix contains proofs of our theoretical results and a detailed description of data sources.

\section{Theoretical Framework}

In this section we develop a simple theoretical model of credit rationing to derive formal predictions on how the probability that an FDI project receives funding depends on parameters representing the collateral channel, the lending channel, as well as characteristics of the firm and the bank-firm relationship. The model features two possible financial frictions, namely incomplete information on the part of lenders about the success probability of an investment project, and incomplete credit contracts. Incomplete information leads to credit rationing. This component of the model is based on Besanko and Thakor (1987), but uses a continuous distribution of types in order to identify a cut-off level of success probability that separates low-probability projects that do not receive bank financing from high-probability projects that are funded. Incomplete contracts imply the use of collateral. We assume

\footnotetext{
${ }^{5}$ Further empirical evidence shows that the recent decrease in world trade has been partly due to the worldwide credit crunch (see Chor and Manova, 2012, Freund and Klapper, 2009), and that financial constraints affect foreign activity (Manova et al., 2009). There is some evidence that FDI is even more vulnerable to credit constraints than exports (see Buch et. al. (2010)).
} 
that the success of the project is either not or only partly verifiable. This means that an investor could claim that the project was not successful, and by claiming no success the investor could renege on repaying the loan plus interest. In this case, the lender would only be left with the collateral. Hence the lender will always want to deter this opportunistic behavior and will do so by specifying a collateral that makes the investor just indifferent between repaying and reneging. ${ }^{6}$

In our model, the lender is a single bank that deals with the investor. Although Japanese firms tend to borrow from several banks, this assumption is consistent with the empirical observation that Japanese firms have strong ties with their main bank. It also has the advantage of giving us a clear starting point for our theoretical analysis: In this setup, it is well known that collateral is an inefficient sorting device for the asymmetric information problem and would not be used if contracts were complete (see Besanko and Thakor, 1987). ${ }^{7}$ Therefore, collateral is used to avoid defection and credit rationing is used to deal with the asymmetric information problem.

Let us now turn to the model in more detail. We assume that a risk-neutral firm has insufficient equity to fund a risky project in a foreign country. If the project is successful, it yields the return $R$ which is common knowledge. In case of failure, the project has a zero payoff. The success probability $q$, however, is private information of the firm. The risk-neutral bank only knows that $q$ is uniformly distributed between $\underline{q}$ and $\bar{q}$. If the firm does not make the investment, it can continue using its equity to yield a safe return of size $\rho$.

The bank offers a loan deal to cover (part of) the investment cost. The bank's policy is a set of offers consisting of a probability $\pi$ of granting credit to the firm and a transfer $T \leq R$ that the firm has to pay the bank (including principal and interest) if the project is successful. Furthermore, the bank asks

\footnotetext{
${ }^{6}$ Classic models on the role of collateral include Barro (1976), Hart and Moore (1994), and Holmstrom and Tirole (1998).

${ }^{7}$ If the banking sector were perfectly competitive, collateral would play a role, but all types would be served in equilibrium (see Bester, 1985). However, there would then be no credit rationing and thus no financial frictions due to asymmetric information. See also Bester (1987) and Schmidt-Mohr (1997).
} 
for a collateral, denoted by $C$, that is liquidated and thus lost by the firm in case of no success.

The loan contract is incomplete insofar as the firm may claim that the project has not been successful. In this case, the firm will appropriate some share $\theta, \theta \in[0,1]$, of the project's return. If $\theta=0$, loan contracts are de facto complete as the firm cannot gain anything by reneging. If $\theta=1$, the firm can default on the loan without cost. More realistic are intermediate values of $\theta$ where the investor cannot capture the whole gross surplus of the project, since hiding returns from a court is costly, for example, because the firm may have to tunnel resources away from the project to other, less profitable business operations. In any case, the bank will always specify the collateral such that reneging is not a profitable option. Thus, the collateral is always set such that $C=\theta R$. As in the literature (see Barro, 1976), we assume that collateral is costly for the investor because the investor is not as good in raising funds as the bank; this is the reason to ask for a loan in the first place. Therefore, there is a disparity in the valuation of the collateral between the bank when it liquidates and the firm when it has to provide collateral, and this means that providing collateral has an additional cost for the investor which we denote by $\gamma C$. An increase in $\gamma$ is thus equivalent to an increase in the cost of collateral.

We set up the model such that the firm applies for a loan from the bank in the first stage, proving any documentation needed to the bank. The bank is able to verify the return on the investment if successful, but not the success probability, and it responds by offering one or more contracts to the firm in the second stage. Each contract specifies $\{\pi, T, C\}$. The firm accepts one contract or rejects them all in the third stage. In case of acceptance, the FDI project is realized and is successful with probability $q$.

Suppose that the bank has offered a single contract $\{\pi, T, C\}$ to the firm. The expected payoff of an investor of type $q$ of accepting the contract is equal to 


$$
\begin{aligned}
U(q) & =\pi(q(R-T)-(1-q) C-\rho-\gamma C) \\
& =\pi(q(R-T)-(1-q) \theta R-\rho-\gamma \theta R),
\end{aligned}
$$

where we have taken into account that $C=\theta R$. The first term is the expected profit from a successful project, the second term is the expected loss from a failed project, and the last two terms are the opportunity costs of the investor's own equity and the cost of the collateral, respectively. Note that $U(q)_{q}=\pi(R-T+C) \geq 0$ so that less risky types have a higher expected payoff. The bank's expected payoff from an accepted deal with type $q$ is equal to

$$
V(q)=\pi(q T+(1-q) C-L),
$$

where $L$ denotes the bank's cost of refinancing the loan.

When will a project be socially desirable? This will be the case for a project of type $q$ if $U(q)+V(q) \geq 0$ for $\theta=0$ which requires that

$$
q \geq \frac{\rho+L}{R} \equiv q^{*}
$$

Without loss of generality, we assume that $q^{*} \geq \underline{q}$ so that there may be projects that are socially undesirable. Under complete information and complete contracts, that is, if the bank learns the type before making an offer and the investor cannot renege on the contract, the optimal policy of the bank would offer a loan to any profitable type and set the transfer such that the firm is just indifferent between acceptance and rejection:

$$
\begin{array}{ll}
\forall q \in\left[\underline{q}, q^{*}[:\right. & \pi(q)=0, \\
\forall q \in\left[q^{*}, \bar{q}\right]: & \pi(q)=1, T(q)=R-\frac{\rho}{q} .
\end{array}
$$

In this case, all socially desirable projects would go ahead, and all socially 
undesirable projects would be scrapped; the financial market works efficiently.

We now make the following assumption:

\section{Assumption 1}

$$
\bar{q} \geq \gamma \theta+\frac{\rho+L}{R}
$$

Assumption 1 will guarantee that the bank will not want to support all socially desirable projects under incomplete information. Under incomplete information, the firm would have an incentive to underreport the riskiness of the project, so $\pi(q)$ and $T(q)$ have to take this into account. We find:

Proposition 1 The optimal policy of the bank under incomplete information is given by

$$
\begin{gathered}
\pi(q)=1 \text { for all } q, \\
T=R(1+\theta)-\rho-\frac{R(1+\gamma) \theta}{\hat{q}}, \\
\hat{q}=\frac{1}{2}\left(\bar{q}+\gamma \theta+\frac{\rho+L}{R}\right), \text { with } \bar{q}>\hat{q}>q^{*},
\end{gathered}
$$

Proof: See Appendix A.1.

Proposition 1 demonstrates that, while granting a loan with probability one, the bank discriminates against bad types by asking for a very high transfer $T$. In particular, $T$ is set so high that all types with a low success probability, $q \in[\underline{q}, \hat{q}]$, do not ask for a loan. On the other hand, good types for which $q \in(\hat{q}, \bar{q}]$ apply for a loan, carry out the investment project, and earn a positive expected rent. The discrimination against bad types implies that some projects that are socially desirable will not go ahead, namely those for which $q \in\left[q^{*}, \hat{q}\right]$.

From (4), we can compute the probability that a firm receives bank financing and thus carries out its investment project, $(\bar{q}-\hat{q}) /(\bar{q}-\underline{q})$, which is inversely related to $\hat{q}$. We can then identify how changes in exogenous parameters affect this probability. In addition to the parameters included in (4), we may define the riskiness of an investment project, $\varepsilon$, by considering a mean-preserving spread of the distribution of $q$ such that $[\underline{q}-\varepsilon, \bar{q}+\varepsilon]$. It is then straightforward to show: 
Proposition 2 The probability that a project is financed is increasing in the project return $R$, and decreasing in the cost of collateral $\gamma$, the bank's refinancing cost $L$, the riskiness of the project $\varepsilon$, the degree of contract incompleteness $\theta$ and the firm's outside option $\rho$.

Proposition 2 shows, among other things, that an increase in the collateral cost and in the refinancing cost both reduce the probability that a project is carried out. Notice, however, that the project that just breaks even in terms of social profitability, $q^{*}$, is independent of the cost of collateral but increases with the cost of bank refinancing; moreover, $q^{*}$ increases more quickly with $L$ than $\hat{q}$. This has interesting implications for the probability that a project will be funded given that it is socially desirable, $(\bar{q}-\hat{q}) /\left(\bar{q}-q^{*}\right)$, and hence for the efficiency with which the financial market allocates funding to projects:

Proposition 3 The probability that a socially desirable project is funded is decreasing in the collateral cost $\gamma$ but increasing in the refinancing cost $L$.

This result implies that even though shocks to the collateral cost and the bank refinancing cost have similarly negative effects on investment, they have a completely different impact on financial market efficiency. This shows how important it is to be able to separate empirically the collateral channel from the lending channel.

Furthermore, since $\hat{q}_{\gamma \theta}=1 / 2>0$, we observe that the marginal effect of the collateral decreases with contract quality, that is, with a lower $\theta$. Thus, we expect that the sensitivity of FDI with respect to collateral is lower if the bank and the firm operate in an environment in which opportunistic behavior is more difficult.

\section{The Data}

We base our empirical analysis on count data on Japanese FDI projects in the United States between 1980 and $1994 .^{8}$ Figure 1 shows that the number

\footnotetext{
${ }^{8}$ See Appendix A.2 for a detailed description of the data, the construction of variables, and data sources.
} 
of FDI projects undertaken by Japanese companies in the United States rose quickly from around 100 a year through the early 1980s to around 500 in 1990 and then fell sharply back to its earlier level. This pattern is remarkable especially when compared with the clearly different FDI pattern (Figure 1) undertaken by firms from other major FDI source countries (Canada, France, Germany, Netherlands, UK). ${ }^{9}$ It is clear that the pattern of Japanese investment counts therefore cannot be explained by changing product market conditions in the United States; instead it has to be driven by factors specific to Japanese investors. ${ }^{10}$

We look at two such factors to do with the Japanese financial market. In our theoretical model these are banks' ability to lend, summarized by the refinancing cost, and investors' ability to borrow, indicated by their cost of providing collateral. Our proxy for the refinancing cost is bank health. Indeed, the drop of FDI after 1990 coincides with a decline in bank health. This is indicated by Table 1, which lists the Moody's ratings of the eleven commercial banks acting as main bank to the multinational investors in our sample. But this table also suggests that credit ratings in the second half of the 1980s certainly did not improve. Banks that received Moody's ratings in 1986, the earliest year for which ratings are available, were all rated Aaa; however, by 1987 two banks (LTCB, Sanwa) had already been downgraded, and all banks suffered at least two downgrades by 1994. In several cases, banks suffered a multiple-level downgrade during a single year; and, by 1994, each bank had suffered on average a downgrade of 3.5 levels. None of the banks were upgraded during our sample period.

When we follow Amiti and Weinstein (2011) in using the market-to-book value as a measure of a bank's health, we observe that average bank health started to decline already around 1985, when the Japanese financial system started to be deregulated and big companies gained limited direct access to

\footnotetext{
${ }^{9}$ Count data on inward FDI from these other source countries comes from the U.S. International Trade Administration's (ITA) dataset on "Foreign Direct Investment into the United States."

${ }^{10}$ This is also suggested by the fact that the pattern of Japanese FDI in Europe follows a similar pattern as Japanese FDI in the United States.
} 
the bond market. ${ }^{11}$ This suggests that bank health cannot explain the sharp increase in FDI projects leading up to 1990, at least not in the sense of the RAC hypothesis which posits a positive relationship between bank health and FDI.

This increase in the number of FDI projects, however, mirrors the steep rise in land prices in the second half of the 1980s. Moreover, after the bursting of the real estate bubble in 1990 we see a steep decline in both land prices and FDI. Since land is the main form of collateral to secure bank loans, we use the value of a firm's land holdings as a proxy for the cost of putting up collateral to secure financing for an investment project. We explain in detail in the Appendix how we compute the market value of each firm's land holding and how we ensure that these values are exogenous to the firm.

Of course, changes in FDI counts will be affected by macroeconomic conditions, including potentially an increase in the relative wealth of Japanese investors driven by an appreciation of the yen and rising stock market values of Japanese firms, i.e., Froot and Stein' RW hypothesis. We control for these and other, possibly unobserved macroeconomic effects at the industry level through industry-time fixed effects. Our identification is therefore through variation at the firm level including in the value of land holdings and the health of the firm's main bank.

Since we have access to detailed firm-level information, we can control for a number of additional firm characteristics, such as total assets (excluding land), total factor productivity (TFP), previous investment experience, market value, cash flow, and firm profitability, that are known to be associated with FDI (see, for instance, Raff et al., 2012), and are also likely to be linked to firm-level parameters of our theoretical model, namely the return of the FDI project, the investing firm's outside option, and the riskiness of the investment project.

In the case of Japanese firms it has been argued that membership in

\footnotetext{
${ }^{11}$ In Japan, where securities markets are not as developed as in the US (Yamori and Murakami, 1999), banks remain the preferred source of credit for investors. In fact, during the height of Japanese outward FDI in the late 1980s and early 1990s, investing firms received $66 \%$ of their borrowed capital from banks (compared to $39 \%$ by U.S. firms during the same time period) [Gibson, 1995].
} 
a keiretsu (or industrial group) allows for better access to credit as compared to non-members, especially if there is a close relationship between the keiretsu member and the keiretsu's main bank (see, for instance, Weinstein and Yafeh, 1998). ${ }^{12}$ We can control for keiretsu membership of each firm and we observe whether a firm and its main bank are in the same keiretsu. We use this information to proxy for the model parameter capturing the degree of contract incompleteness. ${ }^{13}$

It is important to control for firm-level variables and keiretsu membership, because we do observe changes in the characteristics of investing firms over time. As shown in Table 2 the average investor during the period 1987 to 1991 is considerably smaller than the average investor before or after. Measured in terms of total assets (excluding land), we find that the average size of investors fell by $38 \%$ from the 1980-85 to the 1986-90 period, and then rose again by $104 \%$ in the post 1990 period. In terms of TFP, we observe the average producer was approximately 10\% less productive in the 1986-1990 period than either the period before or after. A similar pattern is observed for firms' average market valuations and previous investment experience, which are also lower in the 1986-1990 period. Finally, about three quarters of investors prior to 1986 and after 1991 are keiretsu members; the share of keiretsu members is only about two thirds between 1986 and 1990. Combined, these results suggest that during the FDI boom years some firms that would not normally have undertaken FDI in the United States were able to do so. A possible explanation, of course, is that rising land values enabled these firms to obtain financing for FDI projects.

What does not change over time is the share of cross-border mergers and acquisitions (M\&A) in total FDI projects. This share stays roughly constant at just under $10 \%$, meaning that a little more than $90 \%$ of the projects in

\footnotetext{
${ }^{12}$ Keiretsu-affiliated banks lend to both keiretsu members and non-members. In addition, keiretsu firms do not always have as their main bank a bank affiliated with its keiretsu.

${ }^{13}$ Hoshi et al. (1990) find that distressed firms in Japan perform better when they have strong ties with a main bank or keiretsu, because free-rider problems among creditors and informational asymmetries tend to be smaller.

Hoshi et al. (1991) find that investment is less sensitive to liquidity for Japanese firms with close financial ties to large Japanese banks than for firms without those ties, which suggests that information and incentive problems are smaller.
} 
our sample are greenfield investments. ${ }^{14}$

\section{Empirical Specification and Results}

The theoretical model generates predictions on the probability that a firm receives bank funding to carry out an FDI project. In the data we observe whether a Japanese firm $i$ undertakes an FDI project in the United States in year $t$. We hence create a dummy variable $F D I_{i, t}$ that takes the value of one if firm $i$ makes one or more investments in year $t$ and zero otherwise. We can then estimate a logistic model to determine the likelihood of investment $\operatorname{Pr}\left(F D I_{i, t}\right)$.

Following the predictions of Proposition 2, the estimating equation for our baseline logistic model can be written as:

$$
\begin{aligned}
\operatorname{Pr}\left(F D I_{i, t}\right)=\alpha_{0}+ & \alpha_{1} \text { Investor Landholding }_{i, t-1}+\alpha_{2} \text { BankHealt }_{i, t-1} \\
+ & \alpha_{3} \text { FirmChar }_{i, t-1}+\alpha_{4} \text { BCSK }_{i, t-1} \\
& +\alpha_{5} \text { Investor Landholding }_{i, t-1} \times B C S K_{i, t-1}+\varepsilon_{i, t} .
\end{aligned}
$$

where $\varepsilon_{i, t}$ denotes the robust standard error. The explanatory variables are typically lagged by one year to account for the time lag that exists between the decision to invest and the affiliate's start of operation, which is when the investment appears in our dataset.

Firm $i$ 's cost of collateral, $\gamma$, is assumed to be negatively related to the value of the firm's collateral (Investor Landholding ${ }_{i}$ ). We capture the influence of the refinancing cost, $L$, of the firm's main bank through measures

\footnotetext{
${ }^{14}$ Of course, we do not observe the size of these investments and so the size of M\&A activity may be large and may have even changed over time. The constant share of M\&As is nevertheless an indication that Froot and Stein's RW hypothesis may not be sufficient to explain the pattern of Japanese FDI during the sample period. More precisely, Froot and Stein's theory explicitly posits that an increase in real wealth of foreign investors increases their chance of outbidding local investors in acquiring local firm assets. If this were a driving force behind the observed Japanese FDI pattern, one would expect this to show up in the M\&A share.
} 
of the health of firm $i$ 's main bank (BankHealth ${ }_{i}$ ), assuming that healthier banks have a lower refinancing cost. The project's return $R$, the value of the firm's outside option $\rho$, and the riskiness of the project $\varepsilon$ are controlled through vectors of firm specific characteristics $\left(\right.$ FirmChar $\left._{i}\right)$. The degree of contract incompleteness, $\theta$, is captured through a dummy variable indicating whether or not the bank and its client are in the same keiretsu $\left(B C S K_{i}\right)$. Furthermore, we account for the fact that in the model $\gamma$ and $\theta$ appear multiplicatively through the interaction term Investor Landholding $g_{i} \times B C S K_{i}$. This term captures that the marginal effect of land holdings should be smaller for investors within the same keiretsu as the bank. Finally, we control for variation across both time and industry by a vector of industry-time dummies.

The empirical results of our baseline estimation are summarized in Table 3. We find that both the value of collateral and bank health, when measured by the market-to-book values, have the expected positive and significant effect on the FDI probability. ${ }^{15}$ This is true also for the role of the joint keiretsu membership of the firm and its main bank (BCSK): joint keiretsu membership should reduce opportunistic behavior between investment partners, and as our theoretical model suggests, this increases the likelihood that an investment project receives funding. The InvestorLandholding $\times B C S K$ interaction term also shows the predicted sign: the sensitivity of the FDI probability with respect to the collateral value is significantly smaller for firms in the same keiretsu as their bank. Our results are also in line with the previous findings in the literature that the FDI probability increases with TFP, Total Assets, Cash Flow and the Market Value. More productive or bigger firms and firms with a greater cash flow are more likely to do FDI, because they can more easily cover fixed costs associated with FDI. Firms that have a higher market value are also more likely to engage in FDI, as their relative wealth position makes them more successful when competing against local firms - the RW hypothesis at the firm level. Previous Investment Experience also increases investment likelihood; it may be viewed as reducing the riskiness of the FDI

\footnotetext{
${ }^{15}$ Since the land price index records changes in land prices with a lag, we run the regression separately for "contemporaneous" land holdings and lagged land holdings. But this makes no difference for our results.
} 
project. ${ }^{16}$

The richness of our dataset allows us also to distinguish between new and experienced investors, and between FDI in the core and non-core business lines. New investors could be seen by banks as being riskier or more prone to opportunistic behavior. Non-core investments may also be riskier than core investments. We classify 'new' investors as investors with no previous investment experience in the United States, and thus examine the likelihood of a first investment into the United States. An 'established' investor has at least one previous investment there. The left side of Table 4 shows that bank health and collateral are slightly more important for new investors. A bigger difference is observed for the dummy variable indicating whether the firm belongs to the same keiretsu as the bank. This turns out to be especially important for new investors; contract incompleteness is plausibly a bigger issue in their case. We also find differences in the coefficients on the interaction term between land holding and membership in the same keiretsu as the bank. The coefficients indicate that collateral has a considerably smaller effect on the FDI probability for experienced investors in the same keiretsu as their bank, suggesting that opportunistic behavior may be less of a problem with these investors.

Regarding core and non-core investments, 2-digit SIC codes of the parent and the affiliate determine whether the affiliate is in the parent's 'core' (same 2-digit SIC) or 'non-core' (different 2-digit SIC) business line. Our results from these regressions, found on the right side of Table 4, indicate a similar result as our new/experienced investor regressions regarding the effects of bank health, investor landholding, and keiretsu membership: they have somewhat bigger positive effects on non-core investment. However, when taking into account the interaction term, the differences in the effect of investor land holdings between core and non-core investments are smaller when the firm and the bank are in the same keiretsu.

Do we observe a different impact of bank health and land holding in an FDI boom than in an FDI bust? Is the pattern in the late 1980s and early

\footnotetext{
${ }^{16}$ Replacing Total Assets with Firm Profitability does not affect these results.
} 
1990s different from that in "normal" times, say in the early 1980s? In Table 5 we report the results of separate regressions for the periods 1980-1985, 1986-1990 and 1991-1994. We observe that the coefficients on bank health and investor land holding change very little across periods, except for the land value-BCSK interaction term that is more negative during the 19861990 period, which suggests that the importance of collateral is smaller in keiretsu-based lending during this period.

However, before concluding that the influence of bank health and land values on FDI is stable across the different periods, it is useful to compute quasi-elasticities. ${ }^{17}$ These quasi-elasticities reveal by how many percent the FDI probability changes when there is a $1 \%$ increase in the market-to-book value of the main bank or a $1 \%$ increase in the value of the investor landholding. Table 6 shows that the effects of land values and bank health on the FDI likelihood are economically important. A $1 \%$ increase in the value of its land holding, for instance, raises the likelihood of a firm to engage in FDI by just over $0.2 \%$. Given the huge increase in land prices during the real estate boom in the second half of the 1980s, this translates into a considerable boost to the FDI likelihood. The table also indicates significant variation across time periods in the impact of land holding and much less variation in the impact of bank health. Investor land holding has an especially strong influence on the FDI probability during the real estate boom from 1986 to 1990. Together with the result reported in the previous paragraph that land holding is less important for firms in the same keiretsu as their main bank, this suggests that FDI by firms not related to keiretsu banks is especially affected by the rise in land values. This is consistent with the observation reported earlier that a larger share of FDI projects during these years comes from non-keiretsu firms.

While we use the bank's market-to-book value as our primary measure of bank health, we also check how robust our results are to changes in the bank health measure. To do this, we follow Klein et al. (2002) and use Moody's

\footnotetext{
${ }^{17}$ The computation of quasi-elasticities has to take into account the interaction term, and thus they do not follow simply from the estimated parameters of Table 5 above. The details are available upon request.
} 
long-term deposit ratings as the measure of bank health. This changes our sample period, since Moody's ratings are not available prior to 1986, and only available for our full set of banks beginning in 1988. Using Moody's Aaa rating as the omitted variable, Table 7 shows that bank trouble has an effect on FDI only if a bank is downgraded to Aa3 and below. This shows a general non-linearity in how bank health affects FDI likelihood: as long as the bank rating is not too bad, the FDI probability is not affected. However, once the bank rating drops below Aa2, FDI likelihood is significantly lowered. ${ }^{18}$ Whether we use market-to-book values or Moody's ratings has little impact on the coefficient on land holding and the other explanatory variables.

\section{Conclusions}

The paper demonstrated that financial frictions have statistically significant and economically sizeable effects on FDI. In particular, we identified two separate channels through which financial shocks are transmitted to FDI: a collateral channel and a lending channel. The collateral channel builds on the fact that in Japan and elsewhere land is the primary form of collateral. Changes in the value of its landholdings affect a firm's ability to provide collateral to secure bank financing for its FDI projects. The lending channel, or RAC hypothesis, implies that FDI depends on the ability of banks to provide loans and thus on bank health.

To sort out the collateral and lending channels empirically we relied on microdata on Japanese FDI projects in the United States between 1977 and 1994. This time period is well suited for this task, not only because it exhibits considerable exogenous variation in land prices and in bank health at the firm level, but also because we can be reasonably sure that the big changes in Japanese FDI counts are not driven by changing investment conditions in the United States. FDI into the United States from other source countries

\footnotetext{
${ }^{18}$ For this reason, we have also conducted the analysis with the use of a dummy variable that is 1 if the main bank is rated in the range between $A a a$ and $A a 2$ and 0 if it is rated in the other range. Our results stay surprisingly stable: the dummy variable is significant, but all other variables stay also significant and have the predicted sign in both estimations.
} 
simply does not exhibit the strong pattern we observe in Japanese FDI.

Bank health and the value of land holdings remain significant determinants of FDI throughout the sample period. But it seems fair to say that the big increase in FDI in the second half of the 1980s owes more to the real estate boom than to bank health. Not only do we see land prices soar in this period, but the impact of land holdings on FDI is also much greater at that time than in the sample period as a whole. In particular, the quasi-elasticity of the FDI likelihood with respect to the value of a firm's land holding is about $40 \%$ higher in the 1986-1990 interval. That is, a 1\% increase in the value of land holding raises the probability to engage in FDI by $0.298 \%$, compared to $0.214 \%$ for the sample period as a whole.

Bank health, on the other hand, remains stable or decreases between 1986 and 1990, depending on whether we measure it using Moody's ratings or banks' market-to-book values. Apparently banks were willing to finance the FDI boom at that time and, as our data indicate, to increasingly support projects of smaller firms and firms without keiretsu ties that would not have received funding under "normal" circumstances. Thus an initial weakening of bank health, if there was one, did not discourage FDI, at least not when combined with the apparent rise in the value of collateral. This is not to say that bank health does not matter. Bank health becomes an issue, but only when it has declined sufficiently strongly. That this is the case can be seen most easily in the regressions where we used Moody' ratings to measure bank health. There sufficiently low credit ratings have a significantly negative effect on the FDI probability.

These results once more underline a key result of our paper, namely that the collateral channel plays a substantial and independent role for FDI. Distinguishing this channel from the lending channel is also important when it comes to interpreting what the sharp increase in FDI before 1990 and the subsequent fall mean in terms of financial market efficiency. On the one hand, our theoretical model suggests that a rise in the value of collateral-by decreasing the cost of providing collateral-should permit a greater share of socially desirable projects to receive funding. On the other hand, declining bank health - by raising the cost of refinancing - should force banks to be- 
come more selective in choosing which projects to fund, namely by deterring projects with too small a success probability. During the FDI boom leading up to 1990, banks apparently were not very tough in screening FDI projects; this should not matter if the value of collateral rises and thus allows more socially desirable FDI projects to be financed. However, it seems that land prices in Japan in the late 1980s exceeded their fundamental level, which makes it doubtful that FDI projects were backed by sustainable collateral. ${ }^{19}$

Much more research is needed, of course, before the results we obtained for Japan can be generalized. But one thing we certainly learn is that financial frictions by themselves may have very dramatic consequences for FDI, even if demand conditions remain stable. In light of the Japanese experience, it may appear premature to blame the drastic decline of FDI during the recent world financial crisis only on weak demand and an uncertain regulatory environment.

\section{Appendix}

\section{A.1 Proof of Proposition 1}

In general, (1) can be rewritten as a function of the firm's pretended type, $\widetilde{q}$, and its true type, $q$ :

$$
U(\widetilde{q}, q)=\pi(\widetilde{q})(q(R-T(\widetilde{q}))-(1-q) \theta R-\rho-\gamma \theta R) .
$$

Truthful revelation requires that $U\left(q^{\prime}, q^{\prime}\right) \geq U\left(q^{\prime \prime}, q^{\prime}\right)$ and $U\left(q^{\prime \prime}, q^{\prime \prime}\right) \geq$ $U\left(q^{\prime}, q^{\prime \prime}\right)$ for all $q^{\prime}, q^{\prime \prime} \in[\underline{q}, \bar{q}]$ which leads to the sufficient condition for truthful revelation

$$
\left(q^{\prime}-q^{\prime \prime}\right)\left[\pi^{\prime}\left(R-T^{\prime}\right)-\pi^{\prime \prime}\left(R-T^{\prime \prime}\right)\right] \geq 0,
$$

where the superscripts on $\pi$ and $T$ denote the policies designed for the specific types $q^{\prime}$ and $q^{\prime \prime}$, respectively.

Notice that

\footnotetext{
${ }^{19} \mathrm{~A}$ more thorough analysis of the efficiency implications of the FDI boom is beyond the current paper, as it would require data on affiliate exits to judge ex post the success of FDI projects. Such data are currently not available to us.
} 


$$
\begin{aligned}
U(\widetilde{q}, q)_{\widetilde{q}} & =\dot{\pi}(\widetilde{q})(q(R-T(\widetilde{q})+(1-q) \theta R-\rho-\gamma \theta)-\pi(\widetilde{q}) \dot{T}(\widetilde{q}) \\
U(\widetilde{q}, q)_{q} & =\pi(\widetilde{q})(R-T(\widetilde{q})+\theta R)
\end{aligned}
$$

where the dot denotes the change of the functions with the type. Truthful revelation implies that $U(\widetilde{q}=q, q)_{\widetilde{q}}=0$, and hence that the rent accruing to good types has to increase at a rate $d U(\widetilde{q}=q, q) / d q=U(\widetilde{q}=q, q)_{q}$.

As usual in principal-agent theory, we can find the optimal solution by maximizing the virtual surplus, which consists of the sum of net surpluses of all parties corrected for the increase in rent accruing to good types and weighted by the hazard rate (see, for example, Jullien, 2000). Hence consider maximizing

$$
\int_{\underline{q}}^{\bar{q}}\left[U(q)+V(q)-(\bar{q}-q) U(\widetilde{q}=q, q)_{q}\right] \frac{d q}{\bar{q}-\underline{q}}
$$

over $\pi(q)$ and $T(q)$. Differentiation w.r.t. $\pi(q)$ reveals that the virtual surplus is linear in $\pi(q)$, and thus the optimal $\pi(q)$ is either 0 or 1 , implying that $\dot{\pi}(q)=0$. When $\dot{\pi}(q)=0$ the sufficient condition for truthful revelation (A.2) is fulfilled only if $T(q)=0$. That is, if the bank offers a loan with probability $\pi(q)=1$ to all types $q$, the optimal contract involves the same repayment $T(q)$ from all types. Therefore, the bank has to determine which types it wants to accept its loan contract. This is equivalent to finding the optimal cut-off level $\hat{q}$ such that all worse types do not accept the loan contract and all better types do. At the cut-off level $\hat{q}$ it has to be the case that $U(\hat{q})=0$ so that worse types would make a loss by accepting the contract and better types earn a rent. $U(\hat{q})=0$ implies:

$$
T(\hat{q})=R(1+\theta)-\frac{\rho}{\hat{q}}-\frac{R(1+\gamma) \theta}{\hat{q}} .
$$

Maximization of the expected bank profit

$$
\frac{\bar{q}-\hat{q}}{\bar{q}-\underline{q}}(\hat{q} T(\hat{q})+(1-\hat{q}) \theta R-L)=\frac{\bar{q}-\hat{q}}{\bar{q}-\underline{q}}(\hat{q} R-\rho-\gamma \theta R-L)
$$

over $\hat{q}$ yields

$$
\hat{q}=\frac{1}{2}\left(\bar{q}+\gamma \theta+\frac{\rho+L}{R}\right) .
$$

Assumption 1 guarantees that both $\hat{q}>q^{*}$ and $\hat{q}<\bar{q}$. 


\section{A.2 Description of the Data and Data Sources}

\section{A.2.1 FDI}

We examine count data on Japanese FDI into the United States. These data come from Toyo Keizai Inc.'s Japanese Overseas Investment: A complete listing by firms and countries (JOI). Data collected from the JOI for each investment includes: the name of the Japanese parent; the name, nationality and equity ownership percentage of each investing firm; the date and geographic location of initial investment into the affiliate; and the written description of each affiliate's main business line at the time of initial investment. We limit the sample of investments in two important ways. First, we include an investment only if the principal Japanese investor held an equity ownership share of at least 10\%, which is the standard OECD minimum equity ownership percentage threshold for an investment to be considered FDI. Second, we focus on those investments where the principal investor has as its main bank one of the eleven banks in Klein et al. (2002). The main banks include: Asahi Bank, Dai-Ichi Kango Bank (DKB), Daiwa Bank, Fuji Bank, Industrial Bank of Japan (IBJ), Long-Term Credit Bank (LTCB), Mitsubishi Bank, Sakura Bank, Sanwa Bank, Sumitomo Bank, and Tokai Bank.

There are three primary methods to determine a client firm's main bank: (1) the presence of a bank employee on the firm's board of directors, (2) the bank with the largest shareholding in that firm, and (3) the bank listed as the primary "reference" bank in the Japan Company Handbook (JCH) ${ }^{20}$ To remain consistent with previous studies, especially Klein et al. (2002), the primary reference bank listed in JCH serves as the main bank for our paper. In the few cases where the first bank listed was Norinchukin Bank or the Japan Development Bank, the first listed non-governmental bank serves as the main bank. We are able to identify the investment history of 874 firms 612 firms establish 3323 investments during our sample period, and 262 firms who do not invest in the U.S. ${ }^{21}$

\footnotetext{
${ }^{20}$ Gibson (1995) finds a 95-97\% correlation between the three methods.

${ }^{21}$ Obviously, the influence that primary reference banks may have on their client firms is not homogeneous. For instance, firms that are members of a bank-centered keiretsu may have closer ties to their primary bank than non-members, given the keiretsu structure of information sharing through corporate presidents' council meetings, cross-shareholdings of stock, and the presence of bankers on clients' executive boards (Hoshi, et al., 1991). In addition large firms that list a reference bank may differ in how much credit they require from that bank because of their ability to generate funds from non-bank sources.
} 


\section{A.2.2 Investor Landholding}

Data on Japanese firms' land holdings are found in the Pacific Basin Capital Markets (PACAP) database. This database provides annual data on the firm's land holdings (measured in millions of Yen). As noted by Gan (2007a) and others, Japanese firms are only required to provide the book value of this land, and not the land's market value. Thus, we have to convert the book value of the firms' land holdings to their market value, with this conversion accounting for both land price changes as well as firms' land purchases/sales.

Land values are calculated using the purchase price, which suggests a LIFO accounting technique to convert land prices to market value. However, as Hoshi and Kashyap (1990) indicate, several assumptions must first be made before this calculation can occur. First, we cannot assume that the market and book values of land holdings are the same in our initial period, as a significant divergence between these two values had occurred before the start of the book value time series. Thus, for firms with land holdings prior to 1980, the start of our sample period, we follow Hayashi and Inoue (1991) and Gan (2007a) and multiply the book value of landholdings in 1980 by a factor of 8 to obtain the market value. ${ }^{22}$ For firms that entered our sample after 1980, we assume that the book and market values of their land holdings are equivalent at the time of entry.

Once we have established the market value of the firm's landholdings in 1980, we then allow this value to fluctuate annually only according to changes in Japanese land market values. This creates exogenous fluctuations in a firm's land values, eliminating concerns over endogeneity of land prices that would result from firm land sales/purchases during this period. ${ }^{23}$ Market land values are calculated from the Japanese Urban Land Price Index published by the Japanese Ministry of Internal Affairs and Communication in the Japan Statistical Yearbook. Regional variation in land prices and land price fluctuations exist across Japan during this period, and so we employ regional land price data to calculate market land price fluctuations. The postal code of the firm's headquarter is used to determine regional location. Approximately $85 \%$ of the sample firms are headquartered in one of the major Japanese urban areas, such as Tokyo, Yokohama, and Osaka, for which market land prices are available at the city- or metropolitan-level. Land values

\footnotetext{
${ }^{22}$ Hayashi and Inoue (1991) and Gan (2007a) use the value 7.582446 to calculate this divergence by 1969. Given that we start in 1980, we increased the factor to 8 . Our results, however, are robust to using both 8 and 9 as the initial multiplier.

${ }^{23}$ Note that firms may buy land with a view to using it as collateral in financing FDI projects. Our results are robust to allowing firm land sales/purchases during this period, since average land sales or purchases, relative to the firm's previous year holdings, are actually quite small.
} 
for the remaining firms were calculated using prefecture or national level land values.

\section{A.2.3 Bank Health}

We use two proxies for the health of each investor's main bank: the bank's market-to-book value and its Moody's rating. Applying the market-to-book value allows us to create a longer FDI timeline for our firms, as these data date back to 1977 for many Japanese banks, and 1980 for all of the banks in our sample.

Moody's ratings are, in descending order: Aaa, Aa1, Aa2, Aa3, A1, A2, A3, Baa1, Baa2. As stated in Moody's Moody's Ratings Symbols and Definitions, "Moody's long-term obligation ratings are opinions of the relative credit risk of fixed-income obligations with an original maturity of one year or more. They address the possibility that a financial obligation will not be honored as promised. Such ratings use Moody's Global Scale and reflect both the likelihood of default and any financial loss suffered in the event of default."

\section{A.2.4 Firm Characteristics}

The JOI's verbal description of the affiliate's main business line allows for a clear determination of the affiliate's activities at the 2-digit SIC level. For the few investments for which the JOI does not list an affiliate's main business line information was provided from the main offices of most national foreign investment agencies (e.g. Irish Development Agency). SIC codes for Japan-based investors are found in numerous publicly available sources such as Diamond Lead's Diamond's Japan Business Directory and Toyo Keizai's Japan Company Handbook (various years).

The firm-specific variables contained in the vector FirmChar $_{i, t-1}$ include seven different firm-specific heterogeneity measures intended to capture a wide range of FDI-related firm characteristics. Total Assets, measured as the logarithm of the real value of a firm's total assets (excluding land holdings), where the nominal values are deflated by the Japanese wholesale price index. Market Value is measured as the logarithm of the total market capitalization of the firm. TFP is computed via Levinsohn-Petrin's (2003) method. Previous Investment Experience is a count of the firm's previous FDI projects into the United States. Cash Flow is a measure of an investor's operating cash flow margin. It is calculated as the sum of income from firm operations scaled by total sales. Firm Profitability is calculated as the firm's profits-to-assets ratio. 
Dodwell Marketing's Industrial Groupings in Japan is used to determine keiretsu membership of the investing firms as well as for each bank. For Japanese firms, it has been argued that a keiretsu member's close relationship with the keiretsu's main bank allows increased access to credit as compared to non-members (see, for instance, Weinstein and Yafeh, 1998). Thus, the keiretsu membership status of both the client firm and its main bank potentially act to mitigate the client firm's declining access to credit. However, keiretsu-affiliated banks lend to both keiretsu members and non-members. In addition, keiretsu firms do not always have as its main bank a bank affiliated with its keiretsu.

\section{References}

[1] Aghion, P., M. Angeletos, A. Banerjee and K. Manova (2010), Volatility and Growth: Credit Constraints and the Composition of Investment, Journal of Monetary Economics 57, 246-65.

[2] Alba, Joseph D., Peiming Wang, and Woon-Yee Ho (2007), Relative Access to Credit, Relative Wealth, and FDI: Firm-Level Evidence from Japanese FDI into the United States, Journal of Economic Integration $22,231-255$.

[3] Amiti, Mary and David E. Weinstein (2011), Exports and Financial Shocks. Quarterly Journal of Economics, 126: 1841-1877.

[4] Anderson, Christopher W. and Anil K. Makhija (1999), Deregulation, Disintermediation, and Agency Costs of Debt: Evidence from Japan, Journal of Financial Economics 51, 309-339.

[5] Arikawa, Y. and H. Miyajima (2005), Relationship Banking and Debt Choice: Evidence from Japan. Corporate Governance: An International Review 13, 408-418.

[6] Barba Navaretti, Giorgio and Anthony J. Venables (2004). Multinational Firms in the World Economy, Princeton: Princeton University Press.

[7] Barro, Robert J. (1976), The Loan Market, Collateral, and Rates of Interest, Journal of Money, Credit and Banking 8, 439-456.

[8] Beck, Thorsten (2003), Financial Dependence and International Trade, Review of International Economics 11, 296-316. 
[9] Besanko, D. and A. Thakor (1987), Collateral and Rationing: Sorting Equilibria in Monopolistic and Competitive Credit Markets, International Economic Review 28, 671-689.

[10] Bester, H. (1985), Screening vs. Rationing in Credit Markets with Imperfect Information, American Economic Review 75, 850-855.

[11] Bester, H. (1987), The Role of Collateral in Credit Markets with Imperfect Information, European Economic Review 31, 887-899.

[12] Bremer, Marc and Richard H. Pettway (2002), Information and the market's perceptions of Japanese bank risk: Regulation, environment, and disclosure, Pacific Basin Finance Journal 10, 119-139.

[13] Buch, Claudia. .M., Iris Kesternich, Alexander Lipponer and Monika Schnitzer (2009), Financial Constraints and the Margins of FDI, CEPR Discussion Paper 7444.

[14] Buch, Claudia. .M., Iris Kesternich, Alexander Lipponer and Monika Schnitzer (2010), Exports versus FDI revisited: Does Finance Matter? Deutsche Bundesbank Discussion Paper Series 1: Economic Studies No $03 / 2010$

[15] Chaney, Thomas, David Sraer and David Thesmar (2012), The Collateral Channel: How Real Estate Shocks Affect Corporate Investment, American Economic Review 102, 2381-2409.

[16] Chor, D. and K. Manova (2012), Off the Cliff and Back: Credit Conditions and International Trade during the Global Financial Crisis, Journal of International Economics 87, 117-133.

[17] Foley, C. Fritz and Kalina Manova (2014), Trade, FDI and Corporate Finance, mimeo.

[18] Freund, C. and L. Klapper (2009), Has the Decline in the Supply of Finance Affected Trade during the Crisis?, mimeo, The World Bank.

[19] Froot, K. and J. Stein (1991), Exchange Rates and Foreign Direct Investment: An Imperfect Capital Markets Approach, Quarterly Journal of Economics 106, 1191-1217.

[20] Gan, Jie (2007a), Collateral, Debt Capacity, and Corporate Investment: Evidence from a Natural Experiment, Journal of Financial Economics 85, 709-734. 
[21] Gan, Jie (2007b), The Real Effects of Asset Market Bubbles: Loan- and Firm-Level Evidence of a Lending Channel, Review of Financial Studies 20, 1941-1973.

[22] Gibson, Michael S. (1995), Can Bank Health Affect Investment? Evidence from Japan, Journal of Business 68, 281-308.

[23] Hart, O. and J. Moore (1994), A Theory of Debt Based on the Inalienability of Human Capital, Quarterly Journal of Economics, 109: 841-879.

[24] Hayashi, F. and T. Inoue (1991), The relation between firm growth and Q with multiple capital goods: theory and evidence from panel data on Japanese firms, Econometrica 59: 731-53.

[25] Holmstrom, B. and J. Tirole (1998), Private and Public Supply of Liquidity, Journal of Political Economy 106, 1-40.

[26] Hoshi, Takeo and Anil Kashyap (1990), Evidence on $q$ and Investment for Japanese Firms, Journal of the Japanese and International Economies 4, 371-400.

[27] Hoshi, Takeo, Anil Kashyap, and David Scharfstein (1990), The Role of Banks in Reducing the Costs of Financial Distress in Japan, Journal of Financial Economics 27, 67-88.

[28] Hoshi, Takeo, Anil Kashyap, and David Scharfstein (1991), Corporate Structure, Liquidity, and Investment: Evidence from Japanese Industrial Groups, Quarterly Journal of Economics 106, 33-60.

[29] Hoshi, Takeo and Anil Kashyap (2000), The Japanese Banking Crisis: Where Did It Come From and How Will It End? in: Ben S. Bernanke and Julio J. Rotemberg, NBER Macroeconomics Annual 1999, Vol. 14, MIT University Press 2000, p. 129-212.

[30] Jullien, B. (2000), Participation Constraints in Adverse Selection Models, Journal of Economic Theory, 93: 1-47.

[31] Klein, M.,and E. Rosengren (1994), The Real Exchange Rate and Foreign Direct Investment in the United States: Relative Wealth vs. Relative Wage Effects, Journal of International Economics 36, 373-389.

[32] Klein, Michael W., Peek, Joe, and Eric S. Rosengren (2002) ,Troubled Banks, Impaired Foreign Direct Investment: The Role of Relative Access to Credit, American Economic Review 92, 664-682. 
[33] Kletzer, K. and P. Bardhan (1987), Credit Markets and Patterns of International Trade, Journal of Development Economics 27, 57-70.

[34] Manova, Kalina (2013), Credit Constraints, Heterogeneous Firms, and International Trade, Review of Economic Studies 80, 711-744.

[35] Manova, K., S. Wei and Z. Zhang (2014), Firm Exports and Multinational Activity under Credit Constraints, Review of Economics and Statistics, forthcoming.

[36] Markusen, James R. (2002). Multinational Firms and the Theory of International Trade, Cambridge, MA: MIT Press.

[37] Matsuyama, K. (2005), Credit Market Imperfections and Patterns of International Trade and Capital Flows, Journal of the European Economic Association 3, 714-723.

[38] Peek, Joe, and Eric S. Rosengren (1997), The International Transmission of Financial Shocks: The Case of Japan, American Economic Review 87, 495-505.

[39] Peek, Joe, and Eric S. Rosengren (2000), Collateral Damage: Effects of the Japanese Bank Crisis on Real Activity in the United States, American Economic Review 90, 30-45.

[40] Peek, Joe, and Eric S. Rosengren (2005), Unnatural Selection: Perverse Incentives and the Misallocation of Credit in Japan, American Economic Review 95, 1144-1166.

[41] Raff, Horst, Michael Ryan and Frank Stähler (2012), Firm Productivity and the Foreign-Market Entry Decisions, Journal of Economics and Management Strategy 21, 849-871.

[42] Schmidt-Mohr, U. (1997) Rationing versus collateralization in competitive and monopolistic credit markets with asymmetric information, European Economic Review 41, 1321-1342.

[43] Stiglitz, Joseph E. and Andrew Weiss (1981), Credit Rationing in Markets with Imperfect Information, Americal Economic Review 71, 393410 .

[44] UNCTAD (2004), World Investment Report 2004, United Nations, New York.

[45] UNCTAD (2011), World Investment Report 2011, United Nations, New York. 
[46] Weinstein, David E. and Yishay Yafeh (1998), On the Costs of a BankCentered Financial System: Evidence from the Changing Main Bank Relations in Japan, Journal of Finance 53, 635-672.

[47] Yamori, Nobuyoshi and Akinobu Murakami (1999), Does Bank Relationship Have an Economic Value? The Effect of Main Bank Failure on Client Firms, Economic Letters 65, 115-120. 


\section{Figure}

Figure 1: Annual Counts of New Japanese FDI into US: 1980-1994

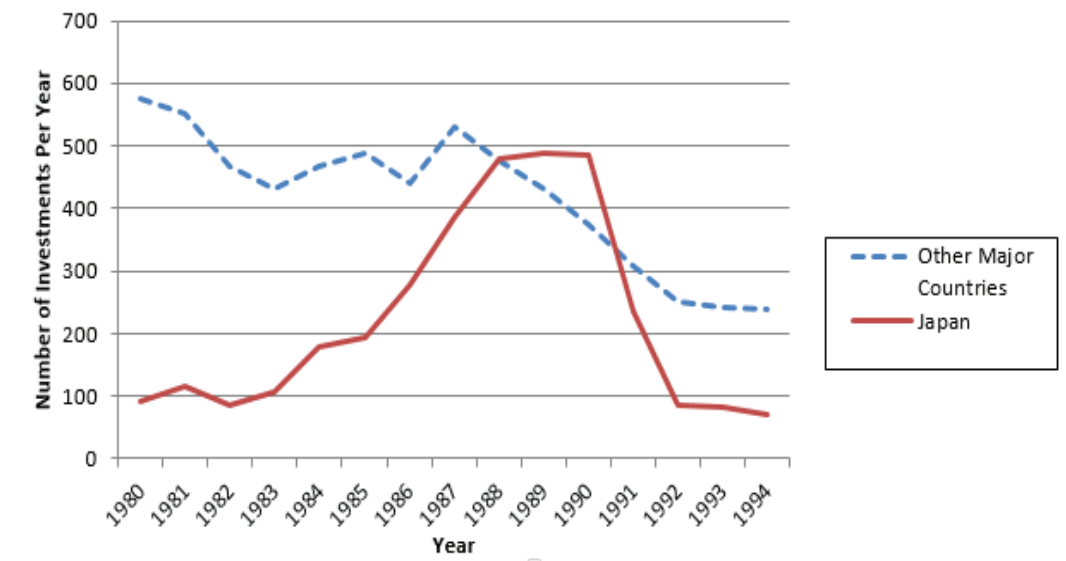

\section{Tables}


Table 1: Japanese Long Term Credit Ratings (Moody's)

\begin{tabular}{l|ccccccccc} 
& 1986 & 1987 & 1988 & 1989 & 1990 & 1991 & 1992 & 1993 & 1994 \\
\hline Asahi Bank & & & Aa3 & Aa3 & Aa3 & Aa3 & A1 & A2 & A2 \\
Dai-Ichi Kangyo Bank & Aaa & Aaa & Aaa & Aaa & Aa1 & Aa1 & Aa3 & A1 & A1 \\
Daiwa Bank & & & & Aa3 & Aa3 & Aa3 & Aa3 & A3 & A3 \\
Fuji Bank & Aaa & Aaa & Aaa & Aaa & Aa1 & Aa3 & Aa3 & A1 & A1 \\
Indus. Bank of Japan & Aaa & Aaa & Aaa & Aaa & Aaa & Aa2 & Aa3 & Aa3 & A1 \\
Long-Term Credit Bank & Aaa & Aa2 & Aa2 & Aa2 & A1 & A2 & A2 & A3 & A3 \\
Mitsubishi Bank & Aaa & Aaa & Aaa & Aaa & Aa1 & Aa1 & Aa3 & Aa3 & Aa3 \\
Sakura Bank & & & Aa2 & Aa3 & Aa3 & A1 & A1 & A2 & A2 \\
Sanwa Bank & Aaa & Aa1 & Aa1 & Aa1 & Aa1 & Aa1 & Aa3 & Aa3 & Aa3 \\
Sumitomo Bank & Aaa & Aaa & Aaa & Aaa & Aa1 & Aa3 & Aa3 & A1 & A1 \\
Tokai Bank & & Aa2 & Aa2 & Aa2 & Aa3 & Aa3 & A1 & A2 & A2 \\
\hline
\end{tabular}

Table 2: Data Descriptive Statistics

\begin{tabular}{|c|c|c|c|}
\hline Average Values & $1980-1985$ & $1986-1990$ & 1991-1994 \\
\hline Market Value of Land ${ }^{a}$ & 77,110 & 105,142 & 98,945 \\
\hline Total (non-land) Assets ${ }^{a}$ & 373,412 & 230,102 & 470,205 \\
\hline TFP & 3.61 & 3.33 & 3.78 \\
\hline Prev. Investment Exp. & 1.93 & 1.29 & 2.14 \\
\hline Keiretsu Membership (\%) & 77.2 & 67.1 & 75.9 \\
\hline Market Value & 18.357 & 19.294 & 18.883 \\
\hline Cash Flow & 0.219 & 0.221 & 0.213 \\
\hline
\end{tabular}

Notes: See Appendix A.2.for details on data construction and sources. a - Millions of Yen. 
Table 3: Firm Level FDI into US Investment 1980-1994

\begin{tabular}{|c|c|c|c|c|c|}
\hline & (1) & 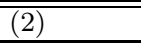 & $(3)$ & $\overline{(4)}$ & \\
\hline \multicolumn{6}{|l|}{ Investor Landholding } \\
\hline \multirow[t]{2}{*}{ Contemporaneous } & $0.937^{* *}$ & $0.918^{* *}$ & & & \\
\hline & $(0.44)$ & $(0.44)$ & & & \\
\hline Contemporaneous*BCSK & & $\begin{array}{l}-0.421^{* * *} \\
(0.13)\end{array}$ & & & \\
\hline \multirow[t]{2}{*}{ 1-Year Lag } & & & $0.902 * *$ & $0.904^{* *}$ & \\
\hline & & & $(0.41)$ & $(0.40)$ & \\
\hline \multirow{2}{*}{ 1-Year Lag*BCSK } & & & & $-0.431^{* * *}$ & \\
\hline & & & & $(0.14)$ & $\underline{\text { Bank Health }}$ \\
\hline \multicolumn{6}{|l|}{$\underline{\text { Bank Health }}$} \\
\hline Market to Book & $\begin{array}{l}0.689^{* *} \\
(0.32)\end{array}$ & $\begin{array}{l}0.700^{* *} \\
(0.33)\end{array}$ & $\begin{array}{l}0.712^{* *} \\
(0.32)\end{array}$ & $\begin{array}{l}0.701^{* *} \\
(0.33)\end{array}$ & Investor Firm-Level Variables \\
\hline \multicolumn{6}{|l|}{ Investor Firm-Level Variables } \\
\hline$\overline{\text { Total Assets }^{a}}$ & $\begin{array}{l}0.310^{*} \\
(0.18)\end{array}$ & $\begin{array}{l}0.318^{*} \\
(0.11)\end{array}$ & $\begin{array}{l}0.312^{*} \\
(0.17)\end{array}$ & $\begin{array}{l}0.317^{*} \\
(0.18)\end{array}$ & \\
\hline TFP & $\begin{array}{l}1.132^{* *} \\
(0.53)\end{array}$ & $\begin{array}{l}1.127^{* *} \\
(0.53)\end{array}$ & $\begin{array}{l}1.137^{* *} \\
(0.52)\end{array}$ & $\begin{array}{l}1.118^{* *} \\
(0.50)\end{array}$ & \\
\hline Prev. Invest. Exp. & $\begin{array}{l}0.702^{* *} \\
(0.32)\end{array}$ & $\begin{array}{l}0.699^{* *} \\
(0.32)\end{array}$ & $\begin{array}{l}0.689^{* *} \\
(0.31)\end{array}$ & $\begin{array}{l}0.694^{* *} \\
(0.31)\end{array}$ & \\
\hline Bank-Client Same Keiretsu & $\begin{array}{l}1.112^{* * * *} \\
(0.41)\end{array}$ & $\begin{array}{l}1.104^{* * *} \\
(0.37)\end{array}$ & $\begin{array}{l}1.098^{* * *} \\
(0.38)\end{array}$ & $\begin{array}{l}1.124^{* * * *} \\
(0.37)\end{array}$ & \\
\hline Market Value & $\begin{array}{l}0.371^{*} \\
(0.20)\end{array}$ & $\begin{array}{l}0.391^{*} \\
(0.20)\end{array}$ & $\begin{array}{l}0.401^{*} \\
(0.22)\end{array}$ & $\begin{array}{l}0.386^{*} \\
(0.20)\end{array}$ & \\
\hline Cash Flow & $\begin{array}{l}0.311^{* *} \\
(0.15)\end{array}$ & $\begin{array}{l}0.302^{* *} \\
(0.13)\end{array}$ & $\begin{array}{l}0.313^{* *} \\
(0.14)\end{array}$ & $\begin{array}{l}0.321^{* *} \\
(0.15)\end{array}$ & \\
\hline $\mathrm{N}$ & 19471 & 19471 & 17863 & 17863 & \\
\hline Wald $\chi^{2}$ & 297.456 & 302.513 & 310.416 & 307.218 & \\
\hline Prob $>\mathrm{F}$ & 0.000 & 0.000 & 0.000 & 0.000 & \\
\hline Pseudo LogLikelihood & -1710.113 & -1801.573 & -1801.748 & -1796.314 & \\
\hline
\end{tabular}

Notes: Logit Model, log odds ratio reported. Market Value of Landholdings measured in Billions of Yen.

Robust standard errors in parenthesis. ${ }^{* * *},{ }^{* * *}$-Significant at the $10 \%, 5 \%$, and $1 \%$ level, respectively.

Industry-time dummies used but not reported. a - Excluding land. 
Table 4: New vs. Established Investors, Core vs. Non-Core Affiliates

\begin{tabular}{l|ll|ll}
\hline \hline & New Investor & Established Investor & Core Investment & Non-Core Investment \\
\hline Investor Landholding & & & & \\
1-year Lag & $0.827^{* *}$ & $0.804^{* *}$ & $0.913^{* *}$ & $1.143^{* *}$ \\
& $(0.39)$ & $(0.38)$ & $(0.42)$ & $(0.49)$ \\
1-year Lag*BCSK & $-0.189^{*}$ & $-0.240^{* *}$ & $-0.174^{*}$ & $-0.297^{* *}$ \\
& $(0.10)$ & $(0.11)$ & $(0.09)$ & $(0.13)$ \\
& & & \\
Bank Health & & & $1.032^{* *}$ & $1.111^{* *}$ \\
Market to Book & $1.014^{* *}$ & $0.981^{* *}$ & $(0.48)$ & $(0.49)$ \\
& $(0.47)$ & $(0.46)$ & & \\
Investor Firm-Level Variables & & & \\
TFP & $0.603^{* *}$ & $0.708^{* *}$ & $0.641^{* *}$ & $0.758^{* *}$ \\
Bank-Client Same Keiretsu & $0.27)$ & $(0.33)$ & $(0.31)$ & $(0.35)$ \\
& $0.701^{* *}$ & $0.522^{* *}$ & $0.751^{* *}$ & $0.812^{* *}$ \\
$\mathrm{~N}$ & $(0.35)$ & $(0.25)$ & $(0.33)$ & $(0.35)$ \\
Wald $\chi^{2}$ & 8102 & 11369 & 16355 & 3115 \\
Prob >F & 197.421 & 212.387 & 238.467 & 108.817 \\
Pseudo LogLikelihood & 0.000 & 0.000 & 0.000 & 0.000 \\
\hline \hline & -914.371 & -1108.641 & -1177.418 & -543.258 \\
\hline
\end{tabular}

Notes: Logit Model, log odds reported. Industry-time dummies and other firm-level variables included in regression, but omitted here for space considerations. Market Value of Landholdings measured in Billions of Yen. Robust standard errors in parenthesis. ***,*** -Significant at the $10 \%, 5 \%$, and $1 \%$ level, respectively. 
Table 5: Japanese FDI into US, split samples

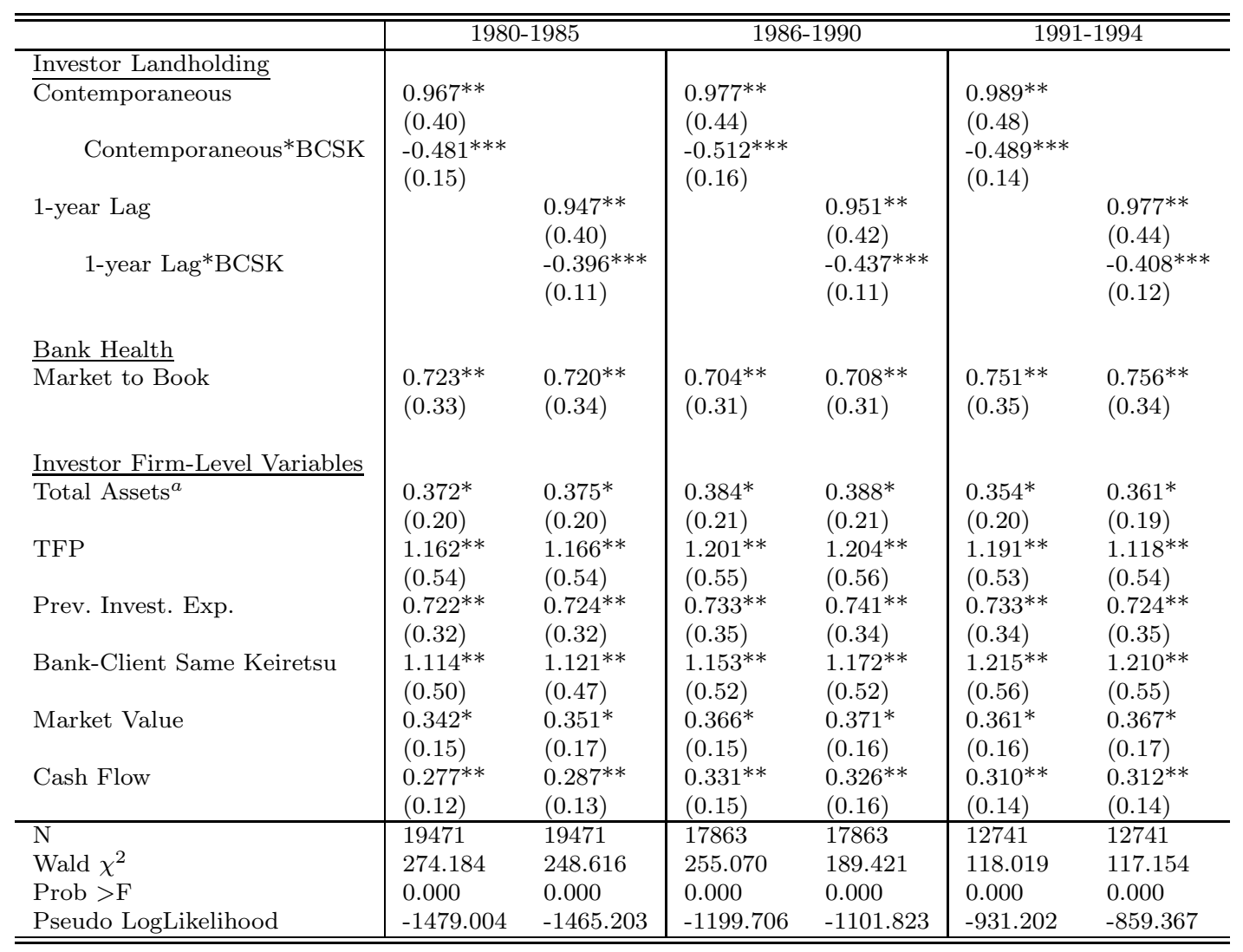

Notes: Logit Model, log odds reported. Market Value of Landholdings measured in Billions of Yen. Robust standard errors in parenthesis. *,*,*** -Significant at the $10 \%, 5 \%$, and $1 \%$ level, respectively. Industrytime dummies used but not reported. a - Excluding land.

Table 6: Quasi-Elasticities

\begin{tabular}{l|c|c|c|c}
\hline \hline & Full Sample & \multicolumn{1}{c}{$1986-1990$} & \multicolumn{1}{c}{$1986-1990$} & \multicolumn{1}{c}{$1991-1994$} \\
\hline Market to Book & 0.220 & 0.204 & 0.237 & 0.201 \\
Investor Landholding & 0.214 & 0.187 & 0.298 & 0.237 \\
\hline
\end{tabular}


Table 7: FDI into US, using Moody's Ratings as Bank Health Measure

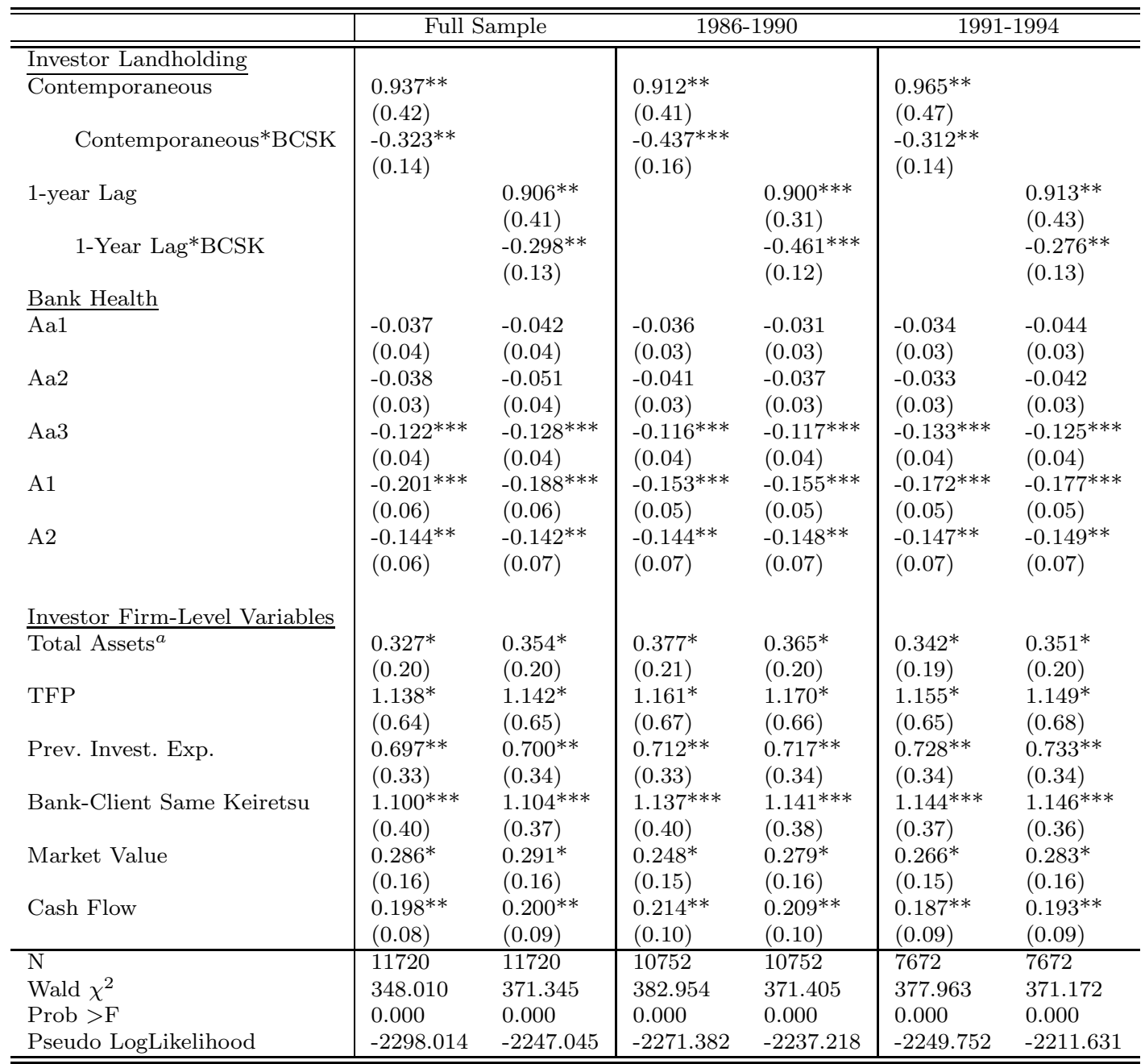

Notes: Logit Model, log odds reported. Market Value of Landholdings measured in Billions of Yen. Robust standard errors in parenthesis. ${ }^{* * *},{ }^{* * *}$-Significant at the $10 \%, 5 \%$, and $1 \%$ level, respectively. Moody's 'Aaa'is the omitted rating. Industry-time dummies used but not reported. a - Excluding land. 